\title{
Limbic Neuropeptidergic Modulators of Emotion and Their Therapeutic Potential for Anxiety and Post-Traumatic Stress Disorder
}

\author{
Paul J. Marvar, ${ }^{1}$ Raïl Andero, ${ }^{2}$ Rene Hurlemann, ${ }^{3}$ Tiffany R. Lago, ${ }^{4}$ Moriel Zelikowsky, ${ }^{5}$ and \\ Joanna Dabrowska ${ }^{6}$ \\ ${ }^{1}$ Department of Pharmacology \& Physiology, Department of Psychiatry and Behavioral Sciences, George Washington Institute for Neuroscience, \\ George Washington University, Washington, DC, 20037, ${ }^{2}$ Departament de Psicobiologia i de Metodologia de les Ciències de la Salut, Institut de \\ Neurociències, Universitat Autònoma de Barcelona, Barcelona, Spain, 08193. Instituto de Salud Carlos III, Centro de Investigación Biomédica en \\ Red de Salud Mental, CIBERSAM, Madrid, Spain, 28029. ICREA, Pg. Lluís Companys 23, Barcelona, Spain, 08010, ${ }^{3}$ Department of Psychiatry, \\ School of Medicine \& Health Sciences, and Research Center Neurosensory Science, University of Oldenburg, Oldenburg, 26129, Germany, \\ ${ }^{4}$ Department of Psychiatry, Veterans Administration Boston Healthcare System, Boston, Massachusetts, 02130, ${ }^{5}$ Department of Neurobiology and \\ Anatomy, University of Utah, School of Medicine, Salt Lake City, Utah, 84112, and ${ }^{6} \mathrm{Center}$ for the Neurobiology of Stress Resilience and Psychiatric \\ Disorders, Discipline of Cellular and Molecular Pharmacology, Chicago Medical School, Rosalind Franklin University of Medicine and Science, \\ North Chicago, Illinois, 60064
}

Post-traumatic stress disorder (PTSD) is characterized by hypervigilance, increased reactivity to unpredictable versus predictable threat signals, deficits in fear extinction, and an inability to discriminate between threat and safety. First-line pharmacotherapies for psychiatric disorders have limited therapeutic efficacy in PTSD. However, recent studies have advanced our understanding of the roles of several limbic neuropeptides in the regulation of defensive behaviors and in the neural processes that are disrupted in PTSD. For example, preclinical studies have shown that blockers of tachykinin pathways, such as the Tac2 pathway, attenuate fear memory consolidation in mice and thus might have unique potential as early post-trauma interventions to prevent PTSD development. Targeting this pathway might also be beneficial in regulating other symptoms of PTSD, including trauma-induced aggressive behavior. In addition, preclinical and clinical studies have shown the important role of angiotensin receptors in fear extinction and the promise of using angiotensin II receptor blockade to reduce PTSD symptom severity. Additional preclinical studies have demonstrated that the oxytocin receptors foster accurate fear discrimination by facilitating fear responses to predictable versus unpredictable threats. Complementary human imaging studies demonstrate unique neural targets of intranasal oxytocin and compare its efficacy with well-established anxiolytic treatments. Finally, promising data from human subjects have demonstrated that a selective vasopressin $1 \mathrm{~A}$ receptor antagonist reduces anxiety induced by unpredictable threats. This review highlights these novel promising targets for the treatment of unique core elements of PTSD pathophysiology.

Key words: anxiety; angiotensin II; oxytocin; PTSD; tachykinin; vasopressin

Received June 30, 2020; revised Nov. 6, 2020; accepted Nov. 11, 2020.

This work was supported by National Institutes of Health Grants 1R01HL137103-01A1 and 3R01HL137103$02 S 1$ to P.J.M., National Institutes of Health Grants R01MH113007 and R01MH113007-04S1 to J.D., Veterans Administration Advanced Research Fellowship to T.R.L., Intramural Research Program, National Institute of Mental Health Grant ZIAMH002798 to T.R.L. (principal investigator Christian Grillon), National Institutes of Health Grant R00MH108734 to M.Z., Sloan Research Fellowship to M.Z., and Klingenstein-Simons Fellowship to M.Z. R.A. was supported by National Alliance for Research on Schizophrenia and Depression Young Investigator Grant 22434, Ramón y Cajal program RYC2014-15784, RETOS-MINECO SAF2016-76565-R FEDER funds, and ERANET-Neuron JTC 2019 ISCIII AC19/00077. Azevan Pharmaceuticals Inc. provided SRX246 and placebo without charge and funded analysis of plasma samples for drug content.

J.D. reports submission of a provisional patent application entitled: Method and System for Testing for Stress-related Mental Disorders, Susceptibility, Disease Progression, Disease Modulation and Treatment Efficacy (\#62/673447). R.A. declares potential conflict of interest with the patent PCT/US2015/037629 about Tac2 antagonists for treating psychiatric disorders. The remaining authors declare no competing financial interests.

Correspondence should be addressed to Joanna Dabrowska at joanna.dabrowska@rosalindfranklin.edu. https://doi.org/10.1523/JNEUROSCl.1647-20.2020

Copyright $\odot 2021$ the authors

\section{Introduction}

Animals respond to impending threats or signals predicting threats through a combination of behavioral and physiological responses related to fear and anxiety. Fear is an adaptive defensive behavior and is necessary for survival (Paré et al., 2004; Gross and Canteras, 2012; Fanselow, 2018). However, maladaptive processing of fear memories can contribute to stress-related psychiatric disorders, such as post-traumatic stress disorder (PTSD). PTSD is characterized by hypervigilance, inability to properly discriminate between threat and safety, disproportionately higher fear reactivity to unpredictable versus predictable threats, and an inability to extinguish learned fear (Craske et al., 2008; Grillon et al., 2009; Jovanovic et al., 2010). First-line pharmacotherapies for psychiatric disorders have limited therapeutic efficacy in PTSD, and the need for new pharmacotherapies remains largely unmet, as clinical trials of many potential 

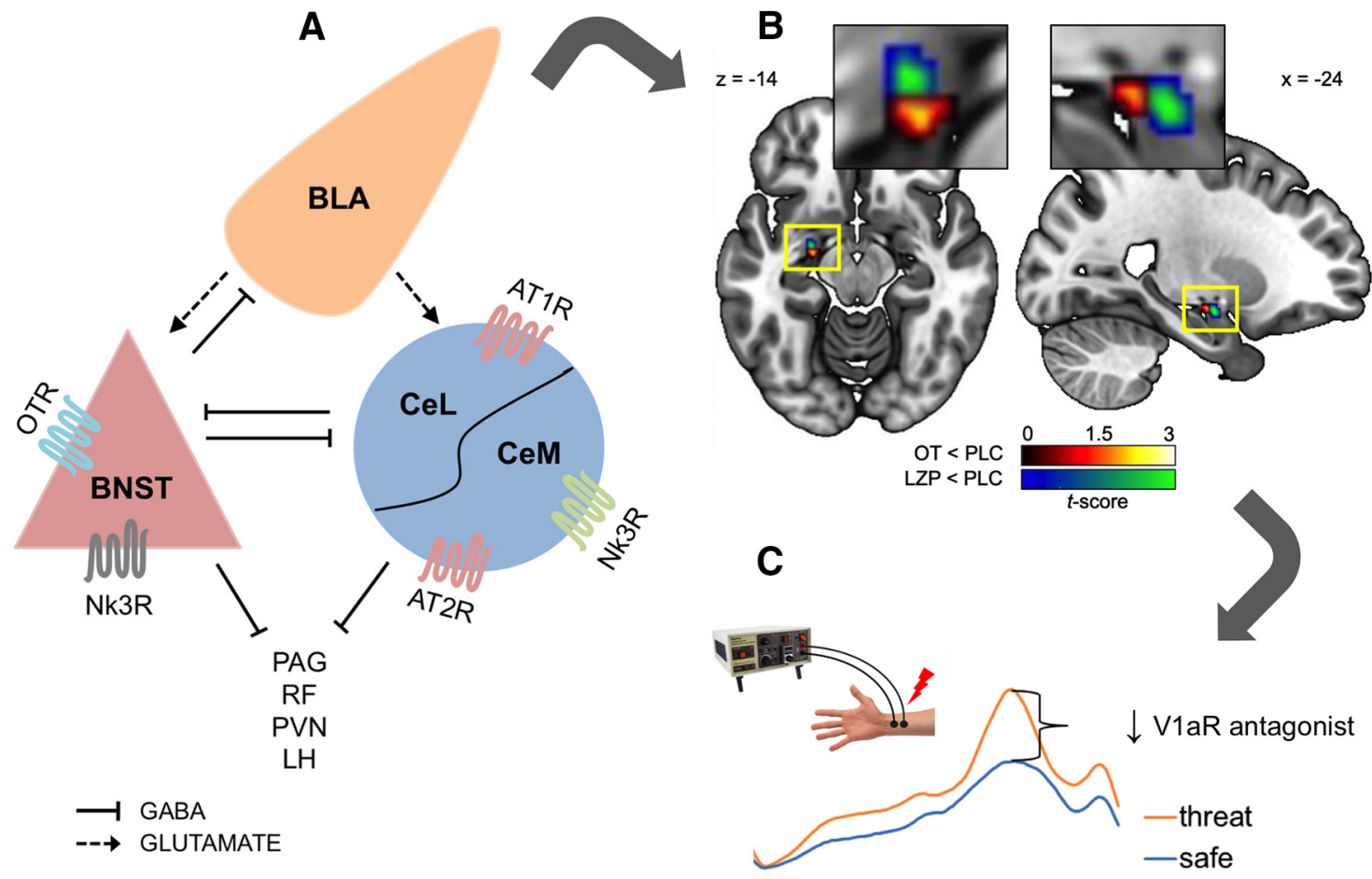

Anxiety-Potentiated Startle

Figure 1. Limbic neuropeptides and their receptors are promising targets for PTSD prevention and treatment. Translational potential of the limbic neuropeptides is illustrated by gray arrows from predinical studies using animals models of fear and anxiety $(\boldsymbol{A})$, to neuroimaging studies on the effects of the neuropeptides (e.g., oxytocin) on the amygdala activity in humans $(\boldsymbol{B})$, to behavioral studies (anxiety-potentiated startle) testing the effects of compounds targeting neuropeptidergic receptors (e.g., vasopressin receptor antagonist) on anxiety measured in humans (C). A, Neuropeptidergic GPCRs in the extended amygdala modulate unique phases of fear learning and thereby can moderate core features of PTSD pathophysiology. OTRs in rat BNST facilitate fear discrimination by strengthening fear responses to predictable, signaled threats. Nk3R-expressing cells in the BNST mediate trauma-induced aggression in mice, whereas in mouse CeM, the Nk3R antagonist osanetant prevents fear memory consolidation. In the CeL and CeM, $\mathrm{AT}_{1} \mathrm{R}$ antagonist accelerates fear memory extinction in mice. LH, Lateral hypothalamus; PAG, periaqueductal gray; RF, reticular formation. Solid lines indicate inhibitory (GABAergic) projections. Dashed arrows indicate excitatory (glutamatergic) projections. B, Using 7T fMRI in healthy human subjects, it was shown that, compared with placebo (PLC), oxytocin (OT, 24IU) dampened the left centromedial amygdala response to fearful relative to neutral faces in a manner similar to lorazepam (LZP, $1 \mathrm{mg}$ ) (red-yellow cluster represents OT vs PLC; blue-green cluster represents LZP vs PLC). C, A novel V1aR antagonist, SRX246, decreases startle amplitude during presentation of an unpredictable threat (mild electrical shock) in a translational paradigm of anxiety in humans. Traces represent processed EMG recordings of eye blink startle after administration of a loud white noise. In the safe condition, participants are not at risk of shock. In the unpredictable threat condition, participants can receive a mild electric shock (red lightning bolt) at any time. Anxiety-potentiated startle is quantified as the change in startle amplitude from safe to threat.

agents, including initially promising corticotropin-releasing factor antagonists, have delivered inconclusive results (Spierling and Zorrilla, 2017). In this review article, we first introduce the brain regions, particularly the extended amygdala, that are critical for the modulation of defensive behaviors and learned fear and describe the basic neurobiology of neuropeptides. We then discuss how basic research on the role of limbic neuropeptides in the regulation of fear and anxiety in animal models is being directly translated into potential treatments for PTSD in humans. The content of the review has an important translational validity with regard to psychiatric disorders in humans because we present data on the effects of the same neuropeptides using clinically relevant measures (e.g., fear-potentiated startle [FPS] and fear conditioning) in both animal and human studies. We also address sex-specific effects in both rodents and humans and the importance of sex-specific pharmacotherapies for PTSD.

\section{The neurocircuitry of fear and anxiety}

The extended amygdala is composed of the central amygdala (CeA) and the bed nucleus of the stria terminalis (BNST) (Sun and Cassell, 1993; Alheid, 2003). Neurons of the extended amygdala are primarily GABAergic and they also produce a vast diversity of neuropeptides, thus forming multiplex neural populations with a wide range of functions (for review, see Beyeler and
Dabrowska, 2020). Both the CeA and the BNST receive afferent glutamatergic information from the BLA among many other regions (Jennings et al., 2013; Torrisi et al., 2018) (Fig. 1A). During fear conditioning (fear memory acquisition), a sensory cue (conditioned stimulus $\left[\mathrm{CS}^{+}\right]$) coterminates with an aversive somatosensory stimulus (unconditioned stimulus [US]), usually a foot shock. When tested for fear recall, animals display fear-like behaviors when presented with the $\mathrm{CS}^{+}$alone and/or in the conditioning context. In the neurocircuitry of fear conditioning, the lateral amygdala (LA) is the main point of entry of sensory inputs (about CS, US, and context) from the thalamus; LA conveys this sensory information to the lateral nucleus of the CeA (CeL) (but see Paré et al., 2004). The CeL projects to the medial CeA (CeM), which is the major output structure of the amygdala (Duvarci and Paré, 2014). Neuronal activity of the LA and CeL is required for fear memory acquisition, whereas activity in the CeM is required for the expression of conditioned fear responses (Pascoe and Kapp, 1985; Fanselow and LeDoux, 1999; Phelps and LeDoux, 2005; Wilensky et al., 2006; Ciocchi et al., 2010).

The BNST also receives direct projections from the CeA and the BLA (Roberts et al., 1982; McDonald et al., 1999). Both the $\mathrm{CeM}$ and the BNST project to many overlapping brainstem effector structures, including the periaqueductal gray (which mediates freezing behavior), reticular formation (which 
produces startle response), lateral hypothalamus (which regulates cardiovascular and respiratory tone), and paraventricular nucleus (PVN) (which secretes various hormones) (Gungor and Paré, 2016; Shackman and Fox, 2016). The CeA and BNST also heavily innervate each other and can modulate each other's activity (Gungor et al., 2015; Pomrenze et al., 2018; Yamauchi et al., 2018) (Fig. 1A).

According to the classic theory formulated by Michael Davis and colleagues (Walker and Davis, 2008; Davis et al., 2010), after a threat stimulus, the CeA is required for fear memory of a short, discrete stimulus (phasic or cued fear), whereas the BNST is necessary for long-duration fear responses (sustained or contextual fear) that resemble anxiety-like behavior. Recently, it has become apparent that the BNST also mediates fear responses to unpredictable, diffuse, or unsignaled threats (Gungor and Paré, 2016; Goode and Maren, 2017; Goode et al., 2019), but it might also inhibit cued fear responses (Meloni et al., 2006; Moaddab and Dabrowska, 2017). Similarly, although the CeA primarily promotes cued fear, it also modulates anxiety-like behavior (Asok et al., 2018; Pomrenze et al., 2018).

\section{Neuropeptidergic modulators versus classic neurotransmitters}

Although neuropeptides were once viewed as having mild neuromodulatory effects, we now know they control a variety of behaviors. In contrast to classic neurotransmitters that are synthesized at the nerve terminal, neuropeptides are synthesized at the cell body and then transported to release sites. They can be released not only from the axonal terminal (axonal release), but also from boutons along the axons, as well as from the soma and dendrites (somatodendritic release). At the release sites, neuropeptides are stored in large dense core vesicles, as opposed to small vesicles, such as those storing classic neurotransmitters (van den Pol, 2012). However, there are some exceptions, as in case of angiotensin II: a network of different brain cells (rather than one cellular phenotype) may contribute to the synthesis and storage of this peptide (for review, see de Kloet et al., 2015). Because large dense core vesicles are stored further back in the terminal than synaptic vesicles, they typically require a prolonged stimulus and a large influx of calcium to be released. Hence, a rapid train of action potentials, rather than a single action potential, is needed to trigger the release of neuropeptides (Bondy et al., 1987). In some cases, however, neuropeptides can be secreted via activity-independent mechanisms, for example, in hypothalamic magnocellular neurons (which produce oxytocin and/or vasopressin), some neurosecretory responses are directly coupled to voltage but independent of internal or external calcium concentrations (for review, see Tasker et al., 2020).

In contrast to classic neurotransmitters, neuropeptides do not possess a reuptake system and are not taken back up into the presynaptic neuron or metabolized in the synapse. As a result, they can diffuse and act at a distance from the release site on a longer time scale than synaptic signaling, in a process called volume transmission (Fuxe et al., 2005). Eventually, neuropeptides are lysed by catabolic peptidases (van den Pol, 2012). Neuropeptide effects are linked to G-protein coupled receptors (GPCRs); therefore, they require more time to have a biological effect, compared with some neurotransmitters acting directly on ion channels and causing an immediate change in neuronal activity. Moreover, the diversity of signaling pathways associated with GPCRs' transmission gives neuropeptides a much broader and more diverse spectrum of biological effects and functions (Hazell et al., 2012). This diversity of signaling pathways also provides vast opportunities for developing new pharmacological targets and treatment strategies.

\section{The role of tachykinins in the consolidation of fear memory and their therapeutic potential for preventing PTSD development}

The tachykinins are a group of peptides sharing a carboxy-terminal sequence; they serve as neuromodulators and neurotransmitters in the mammal brain (Beaujouan et al., 2004). The Tachykinin 1 ( $\operatorname{Tac} 1$ ) gene encodes a pro-protein that, on posttranslational cleavage, produces two peptides: substance P (SP) and neurokinin A. The tachykinin 2 (Tac2) gene encodes neurokinin B (NkB) (Floor et al., 1982). SP binds preferentially to the neurokinin 1 receptor $(\mathrm{Nk} 1 \mathrm{R})$, whereas neurokinin A binds preferentially to the neurokinin 2 receptor and $\mathrm{NkB}$ preferentially binds at the neurokinin 3 receptor (Nk3R) (Khawaja and Rogers, 1996). SP and Nk1R appear to regulate emotional stress responses, and SP in the CSF correlates with PTSD severity (for review, see Dunlop et al., 2012). In addition, the Nk3R receptor regulates fear memory in healthy mice and a PTSD-like model (Dias et al., 2014). Drugs targeting the tachykinin receptors are generally safe and well tolerated in humans (Malherbe et al., 2011; Yuan et al., 2016), raising hopes that they could be used to treat PTSD. To date, however, investigational drugs targeting tachykinin receptors (e.g., the Nk1R antagonist GR205171) have failed to show clinical efficacy in PTSD (Mathew et al., 2011). But unlike Nk1R, which is expressed in multiple areas of the human brain (Beaujouan et al., 2004), Nk3R expression is mainly restricted to the amygdala in mice, rats, rhesus monkeys, and humans (Mileusnic et al., 1999; Duarte et al., 2006; Nagano et al., 2006). Thus, pharmacological targeting of the Nk3R may be a more effective candidate for PTSD treatment. This hypothesis is supported by the discovery that the Tac2 pathway (Tac2, NkB, and Nk3R) plays an important role in fear processing.

A full gene expression analysis of the amygdala after auditory fear conditioning uncovered molecular pathways involved in memory consolidation processes. The top gene candidate identified was Tac2, which was upregulated $30 \mathrm{~min}$ after fear acquisition, while its protein product, $\mathrm{NkB}$, was upregulated at $2 \mathrm{~h}$. Additional experiments revealed that Tac2 is necessary and sufficient for fear memory consolidation in male mice (Andero et al., 2014). Systemic or intra-CeA blockade of the Tac2 pathway via administration of an $\mathrm{Nk} 3 \mathrm{R}$ antagonist reduced fear expression, suggesting it impaired fear memory consolidation. Concordantly, Designer Receptors Exclusively Activated by Designer Drugs (DREADDs)-mediated inhibition of Tac2expressing neurons in the CeA after fear acquisition resulted in diminished fear memory consolidation. In a follow-up study, optogenetic stimulation of channelrhodopsin-expressing CeATac2 neurons during fear acquisition resulted in impaired memory consolidation (Andero et al., 2016). These data highlight the potential of compounds targeting the Tac2 pathway for preventing and/or treating fear-related neuropsychiatric disorders (Fig. 1A). In particular, Nk3R antagonists, such as osanetant, show potential as an early post-trauma intervention against PTSD development because they impair fear memory consolidation in the amygdala.

Future studies on the Tac2 pathway and fear memory should consider the effects of this pathway on sex hormones. Indeed, the oral Nk3R antagonist ESN364 has recently been shown to decrease gonadal hormone levels (testosterone and estradiol/progesterone, respectively) in healthy men and women (Fraser et al., 2016). This is not surprising, given numerous previous reports 
that the Tac2 pathway modulates sex hormones in both male (Danzer et al., 1999) and female rodents (Sahu and Kalra, 1992). Notably, a new study shows that, whereas osanetant impairs fear memory in male mice, it enhances the memory in females (Florido et al., 2020).

\section{The role of Tac2 in trauma-induced aggression}

As described above, Tac2 signaling in the CeA has been shown to play a key role in fear memory consolidation (Andero et al., 2014, 2016). In addition, recent work has implicated Tac2 in encoding the brain state produced by social isolation stress. More specifically, Zelikowsky et al. (2018b) found that prolonged social isolation stress is sufficient to upregulate Tac2 expression across a number of brain regions, and that this upregulation is conserved across species, occurring in mice and fruit flies alike (Zelikowsky et al., 2018a). Furthermore, region-specific loss-offunction perturbations of Tac2 ${ }^{+}$cells, NK3Rs, and Tac2 signaling (using chemogenetics, local Nk3R antagonism, and shRNAi approaches) revealed dissociable roles for the anterior dorsal BNST, dorsomedial hypothalamus, and the CeA in the control of isolation-induced persistent fear, enhanced aggression, and acute fear, respectively. Collectively, these data suggest that Tac2 acts in parallel across multiple brain regions to mediate the effects of social isolation stress on a variety of behaviors.

Of particular interest is the role of tachykinins in isolationinduced aggression. In addition to the findings that Tac2 signaling in the Dorsomedial hypothalamus (DMH) DMH is required for such aggression, Zelikowsky et al. (2018b) demonstrated that virally mediated, brainwide overexpression of Tac2 combined with chemogenetic activation of $\mathrm{Tac}^{+}$cells was sufficient to increase aggressive behavior in otherwise docile group-housed mice. This gain-of-function effect has also been observed in fruit flies (Asahina et al., 2014; Wohl et al., 2020), suggesting a conserved function for tachykinins in controlling aggressive behavior across species.

In addition to examining the role of Tac2 in social isolationinduced aggression, recent studies by Zelikowsky et al. (2018b) have begun to examine the role of Tac2 in mediating aggression produced by an acute stressor. Using a rodent model of PTSD known as stress-enhanced fear learning, these investigations found that a series of inescapable, unsignaled, randomized foot shocks produce a subsequent enhancement in aggressive behavior. This stress-enhanced aggression was found to be mediated by Tac2 signaling.

Despite a role for Tac2 in both isolation-induced aggression and stress-enhanced aggression, the nature of these contributions is distinct. Nonetheless, compounds targeting the Tac2 pathway might provide promising therapeutics for traumainduced aggression (Fig. 1A). This is important because veterans with PTSD exhibit higher incidence of aggressive behavior relative to their non-PSTD veteran counterparts (Chemtob et al., 1994; Jakupcak et al., 2007). Future studies will aim to understand the role of Tac2 in various forms of aggression and its therapeutic potential for attenuating trauma and stressinduced aggression as it relates to PTSD.

\section{The role of angiotensin II in fear extinction and therapeutic opportunities for PTSD}

Growing evidence suggests that the renin angiotensin system (RAS), a regulator of blood pressure and fluid homeostasis, is another potential therapeutic target for PTSD (Khoury et al., 2012; Nylocks et al., 2015; Terock et al., 2019; Zhou et al., 2019). Recent clinical studies demonstrate that losartan, a blocker of the angiotensin type 1 receptor $\left(\mathrm{AT}_{1} \mathrm{R}\right)$, modulates amygdala activity and emotional processing (Pulcu et al., 2019; Zhou et al., 2019) and accelerates fear extinction (Zhou et al., 2019). These clinical studies support many earlier rodent studies demonstrating that brain angiotensin receptors are potent mediators of anxiety-like behavior and stress responsiveness (Okuyama et al., 1999; Shekhar et al., 2006; Saavedra et al., 2011; de Kloet et al., 2016a, 2017).

Angiotensin II is the principal effector peptide of the RAS. Its actions are mediated by binding to its primary receptor subtypes, the $A_{1} R$ and the angiotensin Type 2 receptor $\left(A_{2} R\right)$. These GPCRs are expressed in the periphery and throughout brain circuits involved in fear and anxiety, including the hypothalamus, amygdala, hippocampus, and medial prefrontal cortex (mPFC) (Lind et al., 1985; Gonzalez et al., 2012; de Kloet et al., 2016b). Angiotensin II and associated peptides act on their receptor subtypes following synthesis from enzymatic cleavage of the precursor angiotensinogen (Yang et al., 1999; Grobe et al., 2008). All of the enzymatic components for the synthesis of angiotensin II exist in the brain, including renin, angiotensin converting enzyme (Mendelsohn et al., 1990; Grobe et al., 2008; de Kloet et al., 2015), and more recently discovered (pro)renin and (pro)renin receptor (Xu et al., 2016). Compared with other classic neuropeptides discussed here, brain angiotensin II is therefore unique in that a network of different brain cells (vs one cellular phenotype) may contribute to the synthesis and storage of brain angiotensin II, and thus to its contributions to various physiological and pathophysiological functions, in a regionand cell-specific manner. For further reading, on cellular localization of brain RAS, function, and interaction with other brain cell types, the reader is referred to a recent review (de Kloet et al., 2015).

Brain $\mathrm{AT}_{1} \mathrm{Rs}$ are expressed by neurons involved in stress responses (e.g., the hypothalamic pituitary axis) (Krause et al., 2011) and in limbic regions important for the emotional regulation of fear (Hurt et al., 2015). Notably, inhibition of $\mathrm{AT}_{1}$ Rs has been shown to facilitate fear extinction, a process necessary for recovery from PTSD in both rodents (Marvar et al., 2014; Parrish et al., 2019) and humans (Zhou et al., 2019) (Fig. 1A). Translating between rodent and human studies, Zhou et al. (2019) recently demonstrated that losartan (an $\mathrm{AT}_{1} \mathrm{R}$ antagonist) improved early extinction learning through increased ventromedial PFC (vmPFC) activity and functional connectivity between the vmPFC and the BLA in humans. This enhanced vmPFCBLA coupling could be an important mechanism by which angiotensin II signaling improves fear extinction. Future clinical studies are needed for improving the efficacy of targeting the RAS in fear-based disorders, while application of modern neuroscience technologies will be critical for elucidating the circuits as well as cellular and molecular mechanisms involved in the role of the brain RAS in fear- and anxiety-based disorders (Stout and Risbrough, 2019).

The role of brain Type 2 receptor $\left(\mathrm{AT}_{2} \mathrm{R}\right)$ in fear learning was recently investigated by $\mathrm{Yu}$ et al. (2019) using $\mathrm{AT}_{2} \mathrm{R}$ BAC-eGFP reporter mice. The authors demonstrated that $\mathrm{AT}_{2} \mathrm{R}$-eGFP ${ }^{+}$ neurons were predominantly expressed in the medial amygdala and the CeM, with little $\mathrm{AT}_{2} \mathrm{R}$-eGFP expression in the BLA or $\mathrm{CeL}$. In addition, $\mathrm{AT}_{2} \mathrm{R}$-expressing GABAergic neurons in the $\mathrm{CeA}$ were found to project to the PAG, a midbrain region controlling defensive responses to threat, such as freezing (Yu et al., 2019). These findings suggest that $\mathrm{CeM} \mathrm{AT}_{2} \mathrm{R}$-expressing neurons may modulate $\mathrm{CeA}$ outputs that play a role in fear expression, and they provide new evidence for an angiotensinergic circuit and CeM cell type in the defensive threat response. Brain 
$\mathrm{AT}_{1} \mathrm{Rs}$ and $\mathrm{AT}_{2} \mathrm{Rs}$ may therefore differentially modulate fear memory and threat responding, possibly via inhibitory and excitatory CeA circuits and cortical inputs. Additional studies are needed to test this hypothesis, as well as to further understand angiotensin II signaling pathway interactions with other neuropeptide systems described here.

\section{The role of oxytocin in fostering accurate fear discrimination and strengthening fear responses to predictable threats}

The nonapeptide oxytocin is a hormone and a neuromodulator produced in the PVN, supraoptic nucleus, and an accessory nucleus of the hypothalamus. Oxytocin is released in the extended amygdala, including the CeA and the BNST (Ebner et al., 2005; Martinon et al., 2019), among many other brain regions, where it acts on its single GPCR, the oxytocin receptor (OTR). Oxytocin has shown anxiolytic properties in animal models (Bale et al., 2001; Ring et al., 2006) and human studies (Ellenbogen et al., 2014; for review, see Janeček and Dabrowska, 2019). However, the role of oxytocin in the regulation of fear responses appears more complex (Toth et al., 2012; Guzmán et al., 2013; Lahoud and Maroun, 2013; Campbell-Smith et al., 2015; for review, see Olivera-Pasilio and Dabrowska, 2020). Several studies to date have shown that oxytocin neurons in the hypothalamus are activated during cued and contextual fear conditioning and during fear recall, indicating the recruitment of the endogenous oxytocin system in fear learning in male and female rats (Zhu and Onaka, 2002; Hasan et al., 2019; Martinon et al., 2019). Notably, activation of these oxytocin neurons has been shown to influence the level of contextual fear. For example, as demonstrated using the vGATE system (virus-delivered genetic activity-induced tagging of cell ensembles), optogenetic stimulation of CeL-projecting ensembles of oxytocin neurons activated during fear-conditioning (tagged via vGATE) accelerates extinction of contextual fear in female rats (Hasan et al., 2019). This is consistent with the majority of behavioral studies reporting that activation of OTRs in the CeA reduces contextual fear in male and female rats (Viviani et al., 2011; Knobloch et al., 2012; Terburg et al., 2018).

In apparent contrast, in male rat BNST, OTR neurotransmission has been shown to facilitate cued fear measured as FPS. In the rat FPS paradigm, an acoustic startle reflex (a whole-body jump, which occurs $<200 \mathrm{~ms}$ after a white noise burst) is potentiated by an exposure to a cue (CS, e.g., $3.7 \mathrm{~s}$ light) that has previously been paired with foot shocks (US) during a fear-conditioning session. During the FPS test, rats are presented with startle-eliciting bursts in the presence or absence of the CS (mixed in a pseudorandom order) (Davis et al., 1993; Davis, 2001; Walker and Davis, 2002), and both cued fear and noncued fear are measured. Whereas startle potentiation during cue presentations represents cued fear, startle potentiation observed in between the cue presentations reflects noncued fear. However, the latter startle response does not occur until after the cue is presented (Missig et al., 2010; Moaddab and Dabrowska, 2017; Janeček and Dabrowska, 2019; Walker and Davis, 2002). Therefore, a ratio between cued and noncued fear can be used as a proxy for proper fear discrimination (Janeček and Dabrowska, 2019; Martinon et al., 2019). Notably, studies have also shown that noncued fear (or background anxiety) is independent of contextual fear (Missig et al., 2010; Ayers et al., 2011).

A selective OTR antagonist administered before fear conditioning (acquisition) significantly reduced cued fear and tended to increase noncued fear measured during FPS recall the next day, overall reducing fear discrimination (Moaddab and Dabrowska, 2017; Janeček and Dabrowska, 2019) (Fig.
$1 A)$. Conversely, systemic administration of oxytocin was shown to reduce background anxiety (noncued fear) measured in male rat FPS (Missig et al., 2010; Ayers et al., 2011). These ostensibly contrasting behavioral effects support growing evidence that oxytocin promotes fear discrimination by reducing sustained fear responses (contextual fear and noncued fear) yet strengthening fear responses to signaled, predictable, or imminent threats (Janeček and Dabrowska, 2019; for review, see Olivera-Pasilio and Dabrowska, 2020). Indeed, recent studies investigating the BLA support the role of OTRs in facilitating accurate fear discrimination by selectively strengthening fear responses to discrete cues $\left(\mathrm{CS}^{+}\right)$ (Fam et al., 2018). OTR-mediated transmission in the CeA has also been shown to mediate a switch from passive freezing to active escape behaviors when an animal is confronted with an imminent, yet escapable, threat, while reducing reactivity to distant or diffuse threats (Terburg et al., 2018).

In search of potential mechanisms of these oxytocin effects, electrophysiological studies in the CeA and the BNST have demonstrated that there are two groups of oxytocin-responsive neurons: one group of interneurons that is directly excited by oxytocin and another group of output neurons that is inhibited by oxytocin via an indirect pathway (Huber et al., 2005; Viviani et al., 2011; Knobloch et al., 2012; Francesconi et al., 2020). In the dorsolateral BNST, oxytocin selectively increases the excitability and spontaneous firing of Type I dorsolateral BNST interneurons, and inhibits two classes of projection neurons, including Type II neurons, which project to the CeA (Francesconi et al., 2020). Because BNST activation was shown to induce sustained fear and reduce cued fear (Meloni et al., 2006), activation of OTRs in the BNST might facilitate cued fear and reduce sustained fear responses by inhibiting the BNST output. Thus, reciprocal connectivity between the CeA and the BNST plays a major role in modulating fear discrimination.

In conclusion, oxytocin appears to increase the salience of imminent threat-signaling environmental cues and thereby promote adaptive defensive behaviors while reducing fear responses to unsignaled, distant, or diffuse threats. This is important because increased reactivity to unpredictable threats and impaired fear discrimination are two hallmarks of PTSD. In addition, as patients suffering from PTSD demonstrate increased BNST activity (Awasthi et al., 2020), by ameliorating BNST hyperactivity and improving fear discrimination, oxytocin is a promising target for PTSD pharmacotherapy in humans.

\section{Clinical translation of the fear-modulating effects of oxytocin}

While there is a plethora of pharmacological strategies to modulate oxytocin signaling, the most established approach in humans is through activation of brain OTRs through intranasal administration of synthetic oxytocin (IN-OT) (Gulliver et al., 2019). INOT increases both blood and CSF concentrations of the peptide (Striepens et al., 2013), which accumulates in brain tissue along the trajectories of the olfactory and trigeminal nerves (M. R. Lee et al., 2020). There is also emerging evidence for blood-tobrain transport of oxytocin (M. R. Lee et al., 2018; but see Neumann et al., 2013), which is regulated by the receptor for advanced glycation end-products on brain capillary endothelial cells (Yamamoto and Higashida, 2020).

Current concepts guiding the clinical translation of IN-OT to the treatment of anxiety disorders and PTSD emphasize the following: (1) identification of the neural targets, (2) definition of the most effective dosage needed for target engagement, and 
(3) comparison with clinically established traditional anxiolytics, such as benzodiazepines (Insel, 2016). Given that fMRIbased meta-analyses implicate hyperactivity of the amygdala in response to perceived threats as a common pathophysiological denominator of anxiety disorders and PTSD (Etkin and Wager, 2007), inhibition of the amygdala appears to be essential for the therapeutic control of these conditions with IN-OT. In line with this premise are analyses of oxytocin-pathway gene networks in human postmortem brains, which demonstrate enriched OTR gene expression in subcortical regions, including the amygdala (Quintana et al., 2019).

While there is meta-analytic evidence that IN-OT modulates amygdala responses to perceived threats (Wang et al., 2017), fMRI data characterizing the dose-response profile of this effect were collected only recently. A study conducted in male human subjects found that IN-OT-induced inhibition of amygdala responses to threats was most effective after administration of $24 \mathrm{IU}$, whereas $48 \mathrm{IU}$ evoked an increase in amygdala reactivity (Spengler et al., 2017). The latter was also observed in females after administration of 6,12, or $24 \mathrm{IU}$ (Lieberz et al., 2020), suggesting that IN-OT effects likely vary as a function of dose and sex.

Notably, interplay between the mPFC and the amygdala has been identified as a hallmark of fear extinction learning, which is thought to mediate the efficacy of exposure therapy for anxiety disorders and PTSD. Recently, 7T ultra-high-field fMRI was used to test IN-OT (24 IU) against the benzodiazepine comparator lorazepam ( $1 \mathrm{mg}$ by mouth). While both lorazepam and IN-OT inhibited the centromedial amygdala, only IN-OT effects extended to a functional network, including precuneus and dorsomedial mPFC (Kreuder et al., 2020) (Fig. 1B). Crosstalk between these regions during fear extinction learning was increased by IN-OT (24 IU), along with inhibitory effects on the amygdala per se (Eckstein et al., 2015).

One of the clinical core symptoms of PTSD is intrusive reexperiencing, which can be modeled over days in healthy volunteers exposed to filmed violence. Based on this paradigm, it was shown that IN-OT (24 IU) not only enhanced functional connectivity between the amygdala and mPFC, but also diminished intrusions, at least in subjects who deliberately talked to their peers about what had scared them (Scheele et al., 2019).

A recent meta-analysis confirmed the principle efficacy and safety of IN-OT treatment for PTSD; however, as reflected by preclinical evidence (Lieberz et al., 2020), IN-OT exerts differential, sometimes even opposing, effects in male and female patients with PTSD (Peled-Avron et al., 2020). Modulatory effects of IN-OT (24 IU) on amygdala reactivity (Labuschagne et al., 2010), amygdala-mPFC connectivity (Sripada et al., 2013), and decision-making (Hurlemann et al., 2019) have also been reported for social anxiety disorder; however, the influence of sex as well as the optimal therapeutic dose range for IN$\mathrm{OT}$ in social anxiety disorder are unclear. As a consequence, future clinical trials of IN-OT for anxiety disorders and PTSD should take dose-response as well as person-related effects into account (Andari et al., 2018). Defining the biological determinants of IN-OT treatment will not only inform the clinical translation of oxytocin neuroscience, it will also contribute to establishing personalized care by identifying subgroups of patients with anxiety disorders and PTSD who would benefit most from this novel therapy.

\section{Modulation of unpredictable threat processing by vasopressin}

Preclinical research suggests that the neuropeptide vasopressin may contribute to PTSD, as evidenced by its association with relevant brain regions as well as hormonal and behavioral defensive responses. Neurons in the PVN, suprachiasmatic nuclei, medial amygdala, and BNST synthesize vasopressin (Lu et al., 2019), and vasopressinergic projections are found in the lateral septum and CeA (Hernández et al., 2016; Bredewold and Veenema, 2018). Furthermore, vasopressin plays an important role in activation of the hypothalamic-pituitary-adrenal axis (Rotondo et al., 2016; Nishimura et al., 2019). In rodents, aversive stimuli (e.g., foot shocks) increase vasopressin levels in the PFC and amygdala (Karakilic et al., 2018) and increase vasopres$\sin$ la receptor (V1a) binding in the anterior hypothalamus (Ross et al., 2019). Moreover, intracerebral administration of vasopressin increases anxiety-like behavior (Hernández et al., 2016; Hernández-Pérez et al., 2018), while administration of vasopressin receptor antagonists or knocking out vasopressin receptors decreases anxiety-like behavior (Neumann and Landgraf, 2012; Hodgson et al., 2014; Bayerl et al., 2016). Finally, vasopressin in the lateral septum and BNST enhances aggression (for review, see Carter, 2017; Kompier et al., 2019).

Clinical research on vasopressin has been limited by inconsistent assay methods and restricted pharmacological tools. Nevertheless, researchers have found that early-life stress affects the vasopressin system in both humans and rodents (Hernández et al., 2016; Kompier et al., 2019). Further, vasopressin modulates human neural and physiological responses to negative stimuli across many experimental paradigms (Thompson et al., 2006; Zink et al., 2010; Brunnlieb et al., 2013; R. J. Lee et al., 2013; Motoki et al., 2016). For example, intranasal vasopressin increased physiological arousal (measured with frontalis EMG) during trauma recall in veterans (Pitman et al., 1993). Specific to PTSD, in a longitudinal study of 232 war-exposed children, risk alleles on three genes ( $A V P R 1 a$, which encodes the vasopressin V1a receptor; OXTR, the OTR; and CD38, the cluster of differentiation 38) predicted PTSD development (Feldman et al., 2014). In contrast, plasma vasopressin levels did not predict postdeployment development of PTSD in military subjects (Reijnen et al., 2017). Cross-sectionally, de Kloet et al. (2008) found that veterans with PTSD had higher plasma vasopressin levels than controls and that levels positively correlated with avoidance symptoms. However, police officers with PTSD had similar salivary vasopressin levels to trauma-controls (Frijling et al., 2015); and in another study, civilian urinary vasopressin levels negatively correlated with PTSD severity (Marshall, 2013). Discrepant results may stem from type of assay used, timing of assessments relative to disease state, and/or population differences.

The development of a novel and specific V1a receptor antagonist, SRX246 (Azevan Pharmaceuticals), permits the experimental validation of vasopressin's role in the regulation of anxiety and fear in humans. In a proof-of-concept study, T.R.L. et al. (unpublished data) examined the effects of SRX246 in a translational paradigm of fear (i.e., the phasic response to imminent threat) and anxiety (i.e., a sustained response to potential threat) using startle potentiation as a behavioral measure. Each subject ( $n=36,16$ males, 20 females) received placebo and $300 \mathrm{mg}$ of SRX246, in a counterbalanced order, over 5-7 d. The study used a double-blind, crossover, washout design. Researchers administered the NPU (neutral, predictable, unpredictable) threat test to probe physiological responses to threat. During neutral periods, participants are safe from shock (i.e., threat). During predictable periods, any geometric shape on a screen ("cue") indicates risk for shock, and the absence of any shape ("no-cue") indicates safety. During unpredictable periods, participants are at risk for shock at all times. Anxiety-potentiated startle was operationally 
defined as the change in startle scores during no-cue from neutral to unpredictable conditions, and FPS as the change from no-cue to cue during predictable times. Results indicate that SRX246 decreases anxiety-potentiated startle compared with placebo (Fig. $1 C)$. Participants with the highest subjective anxiety scores had the greatest decrease of subjective anxiety with SRX246 compared with placebo. Given that PTSD patients demonstrate higher startle reactivity to unpredictable threat compared with control patients (Grillon et al., 2009), the V1a receptor antagonist may be a novel promising treatment target for PTSD and anxiety.

\section{Conclusion}

In conclusion, in this review, we discussed the unique translational potential of limbic neuropeptides and their receptors for the prevention and treatment of PTSD. We described the role of tachykinins in strengthening fear memory consolidation and the promising effects of $\mathrm{Nk} 3 \mathrm{R}$ antagonists as an early post-trauma intervention against PTSD development. We discussed how Nk3R antagonists might also act against stress- and social isolation-induced aggression. We reviewed the unique potential of angiotensin II antagonists in accelerating fear extinction in both preclinical and clinical studies. Because one of the hallmarks of PTSD is deficit in threat discrimination, we discussed how oxytocin fosters accurate discrimination by strengthening fear responses to predictable or imminent threats yet attenuating fear responses to diffuse or distant threats. We further emphasized the therapeutic potential of intranasal oxytocin, which strengthens functional connectivity between the amygdala and the mPFC in humans, and therefore might facilitate proper fear extinction similarly to angiotensin II antagonists. Finally, we described studies showing that vasopressin $\mathrm{VlaR}$ antagonist attenuates anxiety in the face of unpredictable threats in both male and female human subjects and thus might serve as a new treatment for PTSD (Fig. 1A-C). Collectively, these studies identify multiple neuropeptides as novel and promising targets for the treatment of PTSD and anxiety disorders. However, given the heterogeneity of PTSD symptoms and clinical manifestation, it is likely that therapeutic targeting of one neuropeptide system may show promise for subsets of PTSD-related symptoms. This suggests a need to establish personalized care by identifying subgroups of patients who would benefit most from each treatment. A combination of compounds targeting neuropeptidergic receptors might provide a more comprehensive treatment approach for other patients. For these reasons, further preclinical and clinical studies on interactions among limbic neuromodulators and circuits described here are essential.

\section{References}

Alheid GF (2003) Extended amygdala and basal forebrain. Ann NY Acad Sci 985:185-205.

Andari E, Hurlemann R, Young LJ (2018) A precision medicine approach to oxytocin trials. Curr Top Behav Neurosci 35:559-590.

Andero R, Dias BG, Ressler KJ (2014) A role for Tac2, NkB, and Nk3 receptor in normal and dysregulated fear memory consolidation. Neuron 83:444-454.

Andero R, Daniel S, Guo JD, Bruner RC, Seth S, Marvar PJ, Rainnie D, Ressler KJ (2016) Amygdala-dependent molecular mechanisms of the Tac2 pathway in fear learning. Neuropsychopharmacology 41:2714-2722.

Asahina K, Watanabe K, Duistermars BJ, Hoopfer E, González CR, Eyjólfsdóttir EA, Perona P, Anderson DJ (2014) Tachykinin-expressing neurons control male-specific aggressive arousal in Drosophila. Cell 156:221-235.

Asok A, Draper A, Hoffman AF, Schulkin J, Lupica CR, Rosen JB (2018) Optogenetic silencing of a corticotropin-releasing factor pathway from the central amygdala to the bed nucleus of the stria terminalis disrupts sustained fear. Mol Psychiatry 23:914-922.

Awasthi S, Pan H, LeDoux JE, Cloitre M, Altemus M, McEwen B, Silbersweig D, Stern E (2020) The bed nucleus of the stria terminalis and functionally linked neurocircuitry modulate emotion processing and HPA axis dysfunction in posttraumatic stress disorder. Neuroimage Clin 28:102442.

Ayers LW, Missig G, Schulkin J, Rosen JB (2011) Oxytocin reduces background anxiety in a fear-potentiated startle paradigm: peripheral vs central administration. Neuropsychopharmacology 36:2488-2497.

Bale TL, Davis AM, Auger AP, Dorsa DM, McCarthy MM (2001) CNS region-specific oxytocin receptor expression: importance in regulation of anxiety and sex behavior. J Neurosci 21:2546-2552.

Bayerl DS, Hönig JN, Bosch OJ (2016) Vasopressin V1a, but not V1b, receptors within the PVN of lactating rats mediate maternal care and anxietyrelated behaviour. Behav Brain Res 305:18-22.

Beaujouan JC, Torrens Y, Saffroy M, Kemel ML, Glowinski J (2004) A 25 year adventure in the field of tachykinins. Peptides 25:339-357.

Beyeler A, Dabrowska J (2020) Neuronal diversity of the amygdala and the bed nucleus of the stria terminalis. Handb Behav Neurosci 26:63-100.

Bondy CA, Gainer H, Russell JT (1987) Effects of stimulus frequency and potassium channel blockade on the secretion of vasopressin and oxytocin from the neurohypophysis. Neuroendocrinology 46:258-267.

Bredewold R, Veenema AH (2018) Sex differences in the regulation of social and anxiety-related behaviors: insights from vasopressin and oxytocin brain systems. Curr Opin Neurobiol 49:132-140.

Brunnlieb C, Münte TF, Tempelmann C, Heldmann M (2013) Vasopressin modulates neural responses related to emotional stimuli in the right amygdala. Brain Res 1499:29-42.

Campbell-Smith EJ, Holmes NM, Lingawi NW, Panayi MC, Westbrook RF (2015) Oxytocin signaling in basolateral and central amygdala nuclei differentially regulates the acquisition, expression, and extinction of context-conditioned fear in rats. Learn Mem 22:247-257.

Carter CS (2017) The oxytocin-vasopressin pathway in the context of love and fear. Front Endocrinol (Lausanne) 8:356.

Ciocchi S, Herry C, Grenier F, Wolff SB, Letzkus JJ, Vlachos I, Ehrlich I, Sprengel R, Deisseroth K, Stadler MB, Müller C, Lüthi A (2010) Encoding of conditioned fear in central amygdala inhibitory circuits. Nature 468:277-282.

Chemtob CM, Hamada RS, Roitblat HL, Muraoka MY (1994) Anger, impulsivity, and anger control in combat-related posttraumatic stress disorder. J Consult Clin Psychol 62:827-832.

Craske MG, Kircanski K, Zelikowsky M, Mystkowski J, Chowdhury N, Baker A (2008) Optimizing inhibitory learning during exposure therapy. Behav Res Ther 46:5-27.

Danzer SC, Price RO, McMullen NT, Rance NE (1999) Sex steroid modulation of neurokinin $\mathrm{B}$ gene expression in the arcuate nucleus of adult male rats. Brain Res Mol Brain Res 66:200-204.

Davis M (2001) Fear-potentiated startle in rats. Curr Protoc Neurosci Chapter 8:Unit 8.11A

Davis M, Falls WA, Campeau S, Kim M (1993) Fear-potentiated startle: a neural and pharmacological analysis. Behav Brain Res 58:175-198.

Davis M, Walker DL, Miles L, Grillon C (2010) Phasic vs sustained fear in rats and humans: role of the extended amygdala in fear vs anxiety. Neuropsychopharmacology 35:105-135.

de Kloet CS, Vermetten E, Geuze E, Wiegant VM, Westenberg HG (2008) Elevated plasma arginine vasopressin levels in veterans with posttraumatic stress disorder. J Psychiatr Res 42:192-198.

de Kloet AD, Liu M, Rodríguez V, Krause EG, Sumners C (2015) Role of neurons and glia in the CNS actions of the renin-angiotensin system in cardiovascular control. Am J Physiol Regul Integr Comp Physiol 309: R444-R458.

de Kloet AD, Pitra S, Wang L, Hiller H, Pioquinto DJ, Smith JA, Sumners C, Stern JE, Krause EG (2016a) Angiotensin type-2 receptors influence the activity of vasopressin neurons in the paraventricular nucleus of the hypothalamus in male mice. Endocrinology 157:3167-3180.

de Kloet AD, Wang L, Ludin JA, Smith JA, Pioquinto DJ, Hiller $\mathrm{H}$, Steckelings UM, Scheuer DA, Sumners C, Krause EG (2016b) Reporter mouse strain provides a novel look at angiotensin type-2 receptor distribution in the central nervous system. Brain Struct Funct 221:891-912.

de Kloet AD, Wang L, Pitra S, Hiller H, Smith JA, Tan Y, Nguyen D, Cahill KM, Sumners C, Stern JE, Krause EG (2017) A unique "angiotensin- 
sensitive" neuronal population coordinates neuroendocrine, cardiovascular, and behavioral responses to stress. J Neurosci 37:3478-3490.

Dias BG, Goodman JV, Ahluwalia R, Easton AE, Andero R, Ressler KJ (2014) Amygdala-dependent fear memory consolidation via miR-34a and Notch signaling. Neuron 83:906-918.

Duarte CR, Schütz B, Zimmer A (2006) Incongruent pattern of neurokinin B expression in rat and mouse brains. Cell Tissue Res 323:43-51.

Dunlop BW, Mansson E, Gerardi M (2012) Pharmacological innovations for posttraumatic stress disorder and medication- enhanced psychotherapy. Curr Pharm Des 18:5645-5658.

Duvarci S, Paré D (2014) Amygdala microcircuits controlling learned fear. Neuron 82:966-980.

Ebner K, Bosch OJ, Krömer SA, Singewald N, Neumann ID (2005) Release of oxytocin in the rat central amygdala modulates stress-coping behavior and the release of excitatory amino acids. Neuropsychopharmacology 30:223-230.

Eckstein M, Becker B, Scheele D, Scholz C, Preckel K, Schlaepfer TE, Grinevich V, Kendrick KM, Maier W, Hurlemann R (2015) Oxytocin facilitates the extinction of conditioned fear in humans. Biol Psychiatry 78:194-202.

Ellenbogen MA, Linnen AM, Cardoso C, Joober R (2014) Intranasal oxytocin attenuates the human acoustic startle response independent of emotional modulation. Psychophysiology 51:1169-1177.

Etkin A, Wager TD (2007) Functional neuroimaging of anxiety: a meta-analysis of emotional processing in PTSD, social anxiety disorder, and specific phobia. Am J Psychiatry 164:1476-1488.

Fam J, Holmes N, Delaney A, Crane J, Westbrook RF (2018) Oxytocin receptor activation in the basolateral complex of the amygdala enhances discrimination between discrete cues and promotes configural processing of cues. Psychoneuroendocrinology 96:84-92.

Fanselow MS (2018) The role of learning in threat imminence and defensive behaviors. Curr Opin Behav Sci 24:44-49.

Fanselow MS, LeDoux JE (1999) Why we think plasticity underlying Pavlovian fear conditioning occurs in the basolateral amygdala. Neuron 23:229-232.

Feldman R, Vengrober A, Ebstein RP (2014) Affiliation buffers stress: cumulative genetic risk in oxytocin-vasopressin genes combines with early caregiving to predict PTSD in war-exposed young children. Transl Psychiatry 4:e370.

Floor E, Grad O, Leeman SE (1982) Synaptic vesicles containing substance P purified by chromatography on controlled pore glass. Neuroscience 7:1647-1655.

Florido A, Velasco E, Soto C, Gómez A, Nadal R, Pozo O, Saura C, Andero R (2020) Opposite-sex effects of the Tac2 pathway blockade in fear memory consolidation: implications for fear-related disorders. In review. Available at https://www.researchsquare.com/article/rs-38533/v2.

Francesconi W, Berton F, Olivera-Pasilio V, Dabrowska J (2020) Oxytocin selectively excites interneurons and inhibits output neurons of the bed nucleus of the stria terminalis (BNST). Neuroscience. Available at https:// www.biorxiv.org/content/10.1101/2020.06.24.169466v2.

Fraser GL, Ramael S, Hoveyda HR, Gheyle L, Combalbert J (2016) The NK3 receptor antagonist ESN364 suppresses sex hormones in men and women. J Clin Endocrinol Metab 101:417-426.

Frijling JL, van Zuiden M, Nawijn L, Koch SBJ, Neumann ID, Veltman DJ, Olff M (2015) Salivary oxytocin and vasopressin levels in police officers with and without post-traumatic stress disorder. J Neuroendocrinol 27:743-751.

Fuxe K, Rivera A, Jacobsen KX, Höistad M, Leo G, Horvath TL, Staines W, De la Calle A, Agnati LF (2005) Dynamics of volume transmission in the brain: focus on catecholamine and opioid peptide communication and the role of uncoupling protein 2. J Neural Transm (Vienna) 112:65-76.

Gonzalez AD, Wang G, Waters EM, Gonzales KL, Speth RC, Van Kempen TA, Marques-Lopes J, Young CN, Butler SD, Davisson RL, Iadecola C, Pickel VM, Pierce JP, Milner TA (2012) Distribution of angiotensin type 1a receptor-containing cells in the brains of bacterial artificial chromosome transgenic mice. Neuroscience 226:489-509.

Goode TD, Maren S (2017) Role of the bed nucleus of the stria terminalis in aversive learning and memory. Learn Mem 24:480-491.

Goode TD, Ressler RL, Acca GM, Miles OW, Maren S (2019) Bed nucleus of the stria terminalis regulates fear to unpredictable threat signals. Elife 8: e46525.

Grillon C, Pine DS, Lissek S, Rabin S, Bonne O, Vythilingam M (2009) Increased anxiety during anticipation of unpredictable aversive stimuli in posttraumatic stress disorder but not in generalized anxiety disorder. Biol Psychiatry 66:47-53.

Grobe JL, Xu D, Sigmund CD (2008) An intracellular renin-angiotensin system in neurons: fact, hypothesis, or fantasy. Physiology (Bethesda) 23:187-193.

Gross CT, Canteras NS (2012) The many paths to fear. Nat Rev Neurosci 13:651-658.

Gulliver D, Werry E, Reekie TA, Katte TA, Jorgensen W, Kassiou M (2019) Targeting the oxytocin system: new pharmacotherapeutic approaches. Trends Pharmacol Sci 40:22-37.

Gungor NZ, Paré D (2016) Functional heterogeneity in the bed nucleus of the stria terminalis. J Neurosci 36:8038-8049.

Gungor NZ, Yamamoto R, Paré D (2015) Optogenetic study of the projections from the bed nucleus of the stria terminalis to the central amygdala. J Neurophysiol 114:2903-2911.

Guzmán YF, Tronson NC, Jovasevic V, Sato K, Guedea AL, Mizukami H, Nishimori K, Radulovic J (2013) Fear-enhancing effects of septal oxytocin receptors. Nat Neurosci 16:1185-1187.

Hasan MT, Althammer F, Silva da Gouveia M, Goyon S, Eliava M, Lefevre A, Kerspern D, Schimmer J, Raftogianni A, Wahis J, Knobloch-Bollmann HS, Tang Y, Liu X, Jain A, Chavant V, Goumon Y, Weislogel JM, Hurlemann R, Herpertz SC, Pitzer C, et al. (2019) A fear memory engram and its plasticity in the hypothalamic oxytocin system. Neuron 103:133-146.e8.

Hazell GG, Hindmarch CC, Pope GR, Roper JA, Lightman SL, Murphy D, O'Carroll AM, Lolait SJ (2012) G protein-coupled receptors in the hypothalamic paraventricular and supraoptic nuclei-serpentine gateways to neuroendocrine homeostasis. Front Neuroendocrinol 33:45-66.

Hernández VS, Hernández OR, Perez de la Mora M, Gómora MJ, Fuxe K, Eiden LE, Zhang L (2016) Hypothalamic vasopressinergic projections innervate central amygdala GABAergic neurons: implications for anxiety and stress coping. Front Neural Circuits 10:92.

Hernández-Pérez OR, Crespo-Ramírez M, Cuza-Ferrer Y, Anias-Calderón J, Zhang L, Roldan-Roldan G, Aguilar-Roblero R, Borroto-Escuela DO, Fuxe K, Perez de la Mora M (2018) Differential activation of arginine-vasopressin receptor subtypes in the amygdaloid modulation of anxiety in the rat by arginine-vasopressin. Psychopharmacology (Berl) 235:1015-1027.

Hodgson RA, Mullins D, Lu SX, Guzzi M, Zhang X, Bleickardt CJ, Scott JD, Miller MW, Stamford AW, Parker EM, Varty GB (2014) Characterization of a novel vasopressin $\mathrm{V} 1 \mathrm{~b}$ receptor antagonist, V1B-30N, in animal models of anxiety-like and depression-like behavior. Eur J Pharmacol 730:157-163.

Huber D, Veinante P, Stoop R (2005) Vasopressin and oxytocin excite distinct neuronal populations in the central amygdala. Science 308:245-248.

Hurlemann R, Scheele D, Kinfe TM, Berger R, Philipsen A, Voncken MJ, Kuypers KP, Schruers K (2019) Increased temporal discounting in social anxiety disorder normalizes after oxytocin treatment. Psychother Psychosom 88:55-57.

Hurt RC, Garrett JC, Keifer OP, Linares A, Couling L, Speth RC, Ressler KJ, Marvar PJ (2015) Angiotensin type 1a receptors on corticotropin-releasing factor neurons contribute to the expression of conditioned fear. Genes Brain Behav 14:526-533.

Insel TR (2016) Translating oxytocin neuroscience to the clinic: a National Institute of Mental Health perspective. Biol Psychiatry 79:153-154.

Jakupcak M, Conybeare D, Phelps L, Hunt S, Holmes HA, Felker B, Klevens M, McFall ME (2007) Anger, hostility, and aggression among Iraq and Afghanistan War veterans reporting PTSD and subthreshold PTSD. J Trauma Stress 20:945-954.

Janeček M, Dabrowska J (2019) Oxytocin facilitates adaptive fear and attenuates anxiety responses in animal models and human studies: potential interaction with the corticotropin-releasing factor (CRF) system in the bed nucleus of the stria terminalis (BNST). Cell Tissue Res 375:143-172.

Jennings JH, Sparta DR, Stamatakis AM, Ung RL, Pleil KE, Kash TL, Stuber GD (2013) Distinct extended amygdala circuits for divergent motivational states. Nature 496:224-228.

Jovanovic T, Norrholm SD, Blanding NQ, Davis M, Duncan E, Bradley B, Ressler KJ (2010) Impaired fear inhibition is a biomarker of PTSD but not depression. Depress Anxiety 27:244-251.

Karakilic A, Kizildag S, Kandis S, Guvendi G, Koc B, Camsari GB, Camsari UM, Ates M, Arda SG, Uysal N (2018) The effects of acute foot shock stress on empathy levels in rats. Behav Brain Res 349:31-36.

Khawaja AM, Rogers DF (1996) Tachykinins: receptor to effector. Int J Biochem Cell Biol 28:721-738. 
Khoury NM, Marvar PJ, Gillespie CF, Wingo A, Schwartz A, Bradley B, Kramer M, Ressler KJ (2012) The renin-angiotensin pathway in posttraumatic stress disorder: angiotensin-converting enzyme inhibitors and angiotensin receptor blockers are associated with fewer traumatic stress symptoms. J Clin Psychiatry 73:849-855.

Knobloch HS, Charlet A, Hoffmann LC, Eliava M, Khrulev S, Cetin AH, Osten P, Schwarz MK, Seeburg PH, Stoop R, Grinevich V (2012) Evoked axonal oxytocin release in the central amygdala attenuates fear response. Neuron 73:553-566.

Kompier NF, Keysers C, Gazzola V, Lucassen PJ, Krugers HJ (2019) Early life adversity and adult social behavior: focus on arginine vasopressin and oxytocin as potential mediators. Front Behav Neurosci 13:143.

Krause EG, de Kloet AD, Scott KA, Flak JN, Jones K, Smeltzer MD, UlrichLai YM, Woods SC, Wilson SP, Reagan LP, Herman JP, Sakai RR (2011) Blood-borne angiotensin II acts in the brain to influence behavioral and endocrine responses to psychogenic stress. J Neurosci 31:15009-15015.

Kreuder AK, Scheele D, Schultz J, Hennig J, Marsh N, Dellert T, Ettinger U, Philipsen A, Babasiz M, Herscheid A, Remmersmann L, Stirnberg R, Stöcker T, Hurlemann R (2020) Common and dissociable effects of oxytocin and lorazepam on the neurocircuitry of fear. Proc Natl Acad Sci USA 117:11781-11787.

Labuschagne I, Phan KL, Wood A, Angstadt M, Chua P, Heinrichs M, Stout JC, Nathan PJ (2010) Oxytocin attenuates amygdala reactivity to fear in generalized social anxiety disorder. Neuropsychopharmacology 35:24032413.

Lahoud N, Maroun M (2013) Oxytocinergic manipulations in corticolimbic circuit differentially affect fear acquisition and extinction. Psychoneuroendocrinology 38:2184-2195.

Lee MR, Scheidweiler KB, Diao XX, Akhlaghi F, Cummins A, Huestis MA, Leggio L, Averbeck BB (2018) Oxytocin by intranasal and intravenous routes reaches the cerebrospinal fluid in rhesus macaques: determination using a novel oxytocin assay. Mol Psychiatry 23:115-122.

Lee MR, Shnitko TA, Blue SW, Kaucher AV, Winchell AJ, Erikson DW, Grant KA, Leggio L (2020) Labeled oxytocin administered via the intranasal route reaches the brain in rhesus macaques. Nat Commun 11:2783.

Lee RJ, Coccaro EF, Cremers H, McCarron R, Lu SF, Brownstein MJ, Simon NG (2013) A novel V1a receptor antagonist blocks vasopressin-induced changes in the CNS response to emotional stimuli: an fMRI study. Front Syst Neurosci 7:100.

Lieberz J, Scheele D, Spengler FB, Matheisen T, Schneider L, StoffelWagner B, Kinfe TM, Hurlemann R (2020) Kinetics of oxytocin effects on amygdala and striatal reactivity vary between women and men. Neuropsychopharmacology 45:1134-1140.

Lind RW, Swanson LW, Ganten D (1985) Organization of angiotensin II immunoreactive cells and fibers in the rat central nervous system: an immunohistochemical study. Neuroendocrinology 40:2-24.

Lu Q, Lai J, Du Y, Huang T, Prukpitikul P, Xu Y, Hu S (2019) Sexual dimorphism of oxytocin and vasopressin in social cognition and behavior. Psychol Res Behav Manag 12:337-349.

Malherbe P, Ballard TM, Ratni H (2011) Tachykinin neurokinin 3 receptor antagonists: a patent review (2005-2010). Expert Opin Ther Pat 21:637655.

Marshall AD (2013) Posttraumatic stress disorder and partner-specific social cognition: a pilot study of sex differences in the impact of arginine vasopressin. Biol Psychol 93:296-303.

Martinon D, Lis P, Roman AN, Tornesi P, Applebey SV, Buechner G, Olivera V, Dabrowska J (2019) Oxytocin receptors in the dorsolateral bed nucleus of the stria terminalis (BNST) bias fear learning toward temporally predictable cued fear. Transl Psychiatry 9:140.

Marvar PJ, Goodman J, Fuchs S, Choi DC, Banerjee S, Ressler KJ (2014) Angiotensin type 1 receptor inhibition enhances the extinction of fear memory. Biol Psychiatry 75:864-872.

Mathew SJ, Vythilingam M, Murrough JW, Zarate CA, Feder A, Luckenbaugh DA, Kinkead B, Parides MK, Trist DG, Bani MS, Bettica PU, Ratti EM, Charney DS (2011) A selective neurokinin-1 receptor antagonist in chronic PTSD: a randomized, double-blind, placebo-controlled, proof-of-concept trial. Eur Neuropsychopharmacol 21:221-229.

McDonald AJ, Shammah-Lagnado SJ, Shi C, Davis M (1999) Cortical afferents to the extended amygdala. Ann NY Acad Sci 877:309-338.

Meloni EG, Jackson A, Gerety LP, Cohen BM, Carlezon WA (2006) Role of the bed nucleus of the stria terminalis (BST) in the expression of conditioned fear. Ann NY Acad Sci 1071:538-541.
Mendelsohn FA, Allen AM, Chai SY, McKinley MJ, Oldfield BJ, Paxinos G (1990) The brain angiotensin system: insights from mapping its components. Trends Endocrinol Metab 1:189-198.

Mileusnic D, Lee JM, Magnuson DJ, Hejna MJ, Krause JE, Lorens JB, Lorens SA (1999) Neurokinin-3 receptor distribution in rat and human brain: an immunohistochemical study. Neuroscience 89:1269-1290.

Missig G, Ayers LW, Schulkin J, Rosen JB (2010) Oxytocin reduces background anxiety in a fear-potentiated startle paradigm. Neuropsychopharmacology 35:2607-2616.

Moaddab M, Dabrowska J (2017) Oxytocin receptor neurotransmission in the dorsolateral bed nucleus of the stria terminalis facilitates the acquisition of cued fear in the fear-potentiated startle paradigm in rats. Neuropharmacology 121:130-139.

Motoki K, Sugiura M, Takeuchi H, Kotozaki Y, Nakagawa S, Yokoyama R, Kawashima R (2016) Are plasma oxytocin and vasopressin levels reflective of amygdala activation during the processing of negative emotions? A preliminary study. Front Psychol 7:480.

Nagano M, Saitow F, Haneda E, Konishi S, Hayashi M, Suzuki H (2006) Distribution and pharmacological characterization of primate NK-1 and NK-3 tachykinin receptors in the central nervous system of the rhesus monkey. Br J Pharmacol 147:316-323.

Neumann ID, Landgraf R (2012) Balance of brain oxytocin and vasopressin: implications for anxiety, depression, and social behaviors. Trends Neurosci 35:649-659.

Neumann ID, Maloumby R, Beiderbeck DI, Lukas M, Landgraf R (2013) Increased brain and plasma oxytocin after nasal and peripheral administration in rats and mice. Psychoneuroendocrinology 38:1985-1993.

Nishimura K, Yoshino K, Sanada K, Beppu H, Akiyama Y, Nishimura H, Tanaka K, Sonoda S, Ueno H, Yoshimura M, Maruyama T, Ozawa H, Ueta Y (2019) Effect of oestrogen-dependent vasopressin on HPA axis in the median eminence of female rats. Sci Rep 9:5153.

Nylocks KM, Michopoulos V, Rothbaum AO, Almli L, Gillespie CF, Wingo A, Schwartz AC, Habib L, Gamwell KL, Marvar PJ, Bradley B, Ressler KJ (2015) An angiotensin-converting enzyme (ACE) polymorphism may mitigate the effects of angiotensin-pathway medications on posttraumatic stress symptoms. Am J Med Genet B Genet 168:307-315.

Okuyama S, Sakagawa T, Chaki S, Imagawa Y, Ichiki T, Inagami T (1999) Anxiety-like behavior in mice lacking the angiotensin II type-2 receptor. Brain Res 821:150-159.

Olivera-Pasilio V, Dabrowska J (2020) Oxytocin promotes accurate fear discrimination and adaptive defensive behaviors. Front Neurosci 14:583878.

Paré D, Quirk GJ, Ledoux JE (2004) New vistas on amygdala networks in conditioned fear. J Neurophysiol 92:1-9.

Parrish JN, Bertholomey ML, Pang HW, Speth RC, Torregrossa MM (2019) Estradiol modulation of the renin-angiotensin system and the regulation of fear extinction. Transl Psychiatry 9:36.

Pascoe JP, Kapp BS (1985) Electrophysiological characteristics of amygdaloid central nucleus neurons during Pavlovian fear conditioning in the rabbit. Behav Brain Res 16:117-133.

Peled-Avron L, Abu-Akel A, Shamay-Tsoory S (2020) Exogenous effects of oxytocin in five psychiatric disorders: a systematic review, meta-analyses and a personalized approach through the lens of the social salience hypothesis. Neurosci Biobehav Rev 114:70-95.

Phelps EA, LeDoux JE (2005) Contributions of the amygdala to emotion processing: from animal models to human behavior. Neuron 48:175-187.

Pitman RK, Orr SP, Lasko NB (1993) Effects of intranasal vasopressin and oxytocin on physiologic responding during personal combat imagery in Vietnam veterans with posttraumatic stress disorder. Psychiatry Res 48:107-117.

Pomrenze MB, Tovar-Diaz J, Blasio A, Maiya R, Giovanetti SM, Lei K, Morikawa H, Hopf FW, Messing RO (2018) A corticotropin releasing factor network in the extended amygdala for anxiety. J Neurosci 39:10301043.

Pulcu E, Shkreli L, Holst CG, Woud ML, Craske MG, Browning M, Reinecke A (2019) The effects of the angiotensin II receptor antagonist losartan on appetitive versus aversive learning: a randomized controlled trial. Biol Psychiatry 86:397-404.

Quintana DS, Rokicki J, van der Meer D, Alnæs D, Kaufmann T, CórdovaPalomera A, Dieset I, Andreassen OA, Westlye LT (2019) Oxytocin pathway gene networks in the human brain. Nat Commun 10:668.

Reijnen A, Geuze E, Vermetten E (2017) Individual variation in plasma oxytocin and vasopressin levels in relation to the development of combatrelated PTSD in a large military cohort. J Psychiatr Res 94:88-95. 
Ring RH, Malberg JE, Potestio L, Ping J, Boikess S, Luo B, Schechter LE, Rizzo S, Rahman Z, Rosenzweig-Lipson S (2006) Anxiolytic-like activity of oxytocin in male mice: behavioral and autonomic evidence, therapeutic implications. Psychopharmacology (Berl) 185:218-225.

Roberts GW, Woodhams PL, Polak JM, Crow TJ (1982) Distribution of neuropeptides in the limbic system of the rat: the amygdaloid complex. Neuroscience 7:99-131.

Ross AP, McCann KE, Larkin TE, Song Z, Grieb ZA, Huhman KL, Albers HE (2019) Sex-dependent effects of social isolation on the regulation of arginine-vasopressin (AVP) V1a, oxytocin (OT) and serotonin (5HT) 1a receptor binding and aggression. Horm Behav 116:104578.

Rotondo F, Butz H, Syro LV, Yousef GM, Di Ieva A, Restrepo LM, Quintanar-Stephano A, Berczi I, Kovacs K (2016) Arginine vasopressin (AVP): a review of its historical perspectives, current research and multifunctional role in the hypothalamo-hypophysial system. Pituitary 19:345-355

Sahu A, Kalra SP (1992) Effects of tachykinins on luteinizing hormone release in female rats: potent inhibitory action of neuropeptide $\mathrm{K}$. Endocrinology 130:1571-1577.

Saavedra JM, Sánchez-Lemus E, Benicky J (2011) Blockade of brain angiotensin II AT1 receptors ameliorates stress, anxiety, brain inflammation and ischemia: therapeutic implications. Psychoneuroendocrinology 36:1-18.

Scheele D, Lieberz J, Goertzen-Patin A, Engels C, Schneider L, StoffelWagner B, Becker B, Hurlemann R (2019) Trauma disclosure moderates the effects of oxytocin on intrusions and neural responses to fear. Psychother Psychosom 88:61-63.

Shackman AJ, Fox AS (2016) Contributions of the central extended amygdala to fear and anxiety. J Neurosci 36:8050-8063.

Shekhar A, Johnson PL, Sajdyk TJ, Fitz SD, Keim SR, Kelley PE, Gehlert DR, DiMicco JA (2006) Angiotensin-II is a putative neurotransmitter in lactate-induced panic-like responses in rats with disruption of GABAergic inhibition in the dorsomedial hypothalamus. J Neurosci 26:9205-9215.

Spengler FB, Schultz J, Scheele D, Essel M, Maier W, Heinrichs M, Hurlemann R (2017) Kinetics and dose dependency of intranasal oxytocin effects on amygdala reactivity. Biol Psychiatry 82:885-894.

Spierling SR, Zorrilla EP (2017) Don't stress about CRF: assessing the translational failures of CRF1 antagonists. Psychopharmacology (Berl) 234:1467-1481.

Sripada CS, Phan KL, Labuschagne I, Welsh R, Nathan PJ, Wood AG (2013) Oxytocin enhances resting-state connectivity between amygdala and medial frontal cortex. Int J Neuropsychopharmacol 16:255-260.

Stout DM, Risbrough VB (2019) Angiotensin II signaling and fear extinction: translational evidence and novel receptor targets. Biol Psychiatry 86:874876.

Striepens N, Kendrick KM, Hanking V, Landgraf R, Wüllner U, Maier W, Hurlemann R (2013) Elevated cerebrospinal fluid and blood concentrations of oxytocin following its intranasal administration in humans. Sci Rep 3:3440.

Sun N, Cassell MD (1993) Intrinsic GABAergic neurons in the rat central extended amygdala. J Comp Neurol 330:381-404.

Tasker JG, Prager-Khoutorsky M, Teruyama R, Lemos JR, Amstrong WE (2020) Advances in the neurophysiology of magnocellular neuroendocrine cells. J Neuroendocrinol 32:e12826.

Terburg D, Scheggia D, Triana Del Rio R, Klumpers F, Ciobanu AC, Morgan B, Montoya ER, Bos PA, Giobellina G, van den Burg EH, de Gelder B, Stein DJ, Stoop R, van Honk J (2018) The basolateral amygdala is essential for rapid escape: a human and rodent study. Cell 175:723-735.e16.

Terock J, Hannemann A, Janowitz D, Freyberger HJ, Felix SB, Dörr M, Nauck M, Völzke H, Grabe HJ (2019) Associations of trauma exposure and post-traumatic stress disorder with the activity of the renin-angiotensin-aldosterone-system in the general population. Psychol Med 49:843851.

Thompson RR, George K, Walton JC, Orr SP, Benson J (2006) Sex-specific influences of vasopressin on human social communication. Proc Natl Acad Sci USA 103:7889-7894.

Torrisi S, Gorka AX, Gonzalez-Castillo J, O'Connell K, Balderston N, Grillon C, Ernst M (2018) Extended amygdala connectivity changes during sustained shock anticipation. Transl Psychiatry 8:33.
Toth I, Neumann ID, Slattery DA (2012) Central administration of oxytocin receptor ligands affects cued fear extinction in rats and mice in a timepoint-dependent manner. Psychopharmacology (Berl) 223:149-158.

van den Pol AN (2012) Neuropeptide transmission in brain circuits. Neuron 76:98-115.

Viviani D, Charlet A, van den Burg E, Robinet C, Hurni N, Abatis M, Magara F, Stoop R (2011) Oxytocin selectively gates fear responses through distinct outputs from the central amygdala. Science 333:104107.

Walker DL, Davis M (2002) Quantifying fear potentiated startle using absolute versus proportional increase scoring methods: implications for the neurocircuitry of fear and anxiety. Psychopharmacology (Berl) 164:318328.

Walker DL, Davis M (2008) Role of the extended amygdala in short-duration versus sustained fear: a tribute to Dr. Lennart Heimer. Brain Struct Funct 213:29-42.

Wang D, Yan X, Li M, Ma Y (2017) Neural substrates underlying the effects of oxytocin: a quantitative meta-analysis of pharmaco-imaging studies. Soc Cogn Affect Neurosci 12:1565-1573.

Wilensky AE, Schafe GE, Kristensen MP, LeDoux JE (2006) Rethinking the fear circuit: the central nucleus of the amygdala is required for the acquisition, consolidation, and expression of Pavlovian fear conditioning. J Neurosci 26:12387-12396.

Wohl M, Ishii K, Asahina K (2020) Layered roles of fruitless isoforms in specification and function of male aggression-promoting neurons in Drosophila. Elife 9:e52702.

Xu Q, Jensen DD, Peng H, Feng Y (2016) The critical role of the central nervous system (pro)renin receptor in regulating systemic blood pressure. Pharmacol Ther 164:126-134.

Yamamoto Y, Higashida H (2020) RAGE regulates oxytocin transport into the brain. Commun Biol 3:70.

Yamauchi N, Takahashi D, Sugimura YK, Kato F, Amano T, Minami M (2018) Activation of the neural pathway from the dorsolateral bed nucleus of the stria terminalis to the central amygdala induces anxiety-like behaviors. Eur J Neurosci 48:3052-3061.

Yang G, Gray TS, Sigmund CD, Cassell MD (1999) The angiotensinogen gene is expressed in both astrocytes and neurons in murine central nervous system. Brain Res 817:123-131.

Yu Z, Swiercz AP, Moshfegh CM, Hopkins L, Wiaderkiewicz J, Speth RC, Park J, Marvar PJ (2019) Angiotensin II type 2 receptor-expressing neurons in the central amygdala influence fear-related behavior. Biol Psychiatry 86:899-909.

Yuan DM, Li Q, Zhang Q, Xiao XW, Yao YW, Zhang Y, Lv YL, Liu HB, Lv TF, Song Y (2016) Efficacy and safety of neurokinin-1 receptor antagonists for prevention of chemotherapy-induced nausea and vomiting: systematic review and meta-analysis of randomized controlled trials. Asian Pac J Cancer Prev 17:1661-1675.

Zelikowsky M, Ding K, Anderson DJ (2018a) Neuropeptidergic control of an internal brain state produced by prolonged social isolation stress. Cold Spring Harb Symp Quant Biol 83:97-103.

Zelikowsky M, Hui M, Karigo T, Choe A, Yang B, Blanco MR, Beadle K, Gradinaru V, Deverman BE, Anderson DJ (2018b) The neuropeptide Tac2 controls a distributed brain state induced by chronic social isolation stress. Cell 173:1265-1279.e19.

Zhou F, Geng Y, Xin F, Li J, Feng P, Liu C, Zhao W, Feng T, Guastella AJ, Ebstein RP, Kendrick KM, Becker B (2019) Human extinction learning is accelerated by an angiotensin antagonist via ventromedial prefrontal cortex and its connections with basolateral amygdala. Biol Psychiatry 86:910-920

Zhu L, Onaka T (2002) Involvement of medullary A2 noradrenergic neurons in the activation of oxytocin neurons after conditioned fear stimuli. Eur J Neurosci 16:2186-2198.

Zink CF, Stein JL, Kempf L, Hakimi S, Meyer-Lindenberg A (2010) Vasopressin modulates medial prefrontal cortex-amygdala circuitry during emotion processing in humans. J Neurosci 30:7017-7022. 